\title{
Complex problem analysis of the Hungarian milk product chain
}

\author{
Beáta Blaskó \\ University of Debrecen \\ Centre for Agricultural and Applied Economic Sciences \\ Faculty of Applied Economics and Rural Development \\ Institute of Business Economics, Debrecen \\ blaskob@agr.unideb.hu
}

Key words: Hungarian dairy sector, product chain, problem analysis of the milk product chain

\section{SUMMARY}

\begin{abstract}
Hungarian dairy sector went through significant changes in past two decades. The most significant changes were caused by our accession to the European Union. In Hungary milk production remarkably declined after EU accession. The size of our dairy herd has been practically reducing since the political transformation, but increasing yields per cow could compensate it in some way and for some time. However, in recent years, increasing yield per cow came to a stop and in parallel, the number of cows declined further and faster. Low prices, high production costs and tightening quality requirements ousted several producers from the market in past years. Feeding cost represents the highest rate in cost structure of production, but animal health expenditures and various losses are also significant. There are undeniably competitive disadvantages in the level of organisation and labour productivity; however competitiveness already depends on cost effectiveness in the medium run. In Hungary concentration of the dairies is relatively strong in spite of the relative high number of corporations. The dairies compete with each other and with the export market for the raw material and the better exploitation of their capacities. Applied technology of the Hungarian dairies lags behind the Western-European competitors'; in addition they have handicaps in efficiency and product innovation. Presence of chain of stores being dominant in sale of milk products does also not favour in all respects to the position of the dairies. The aforementioned retail chains are namely consumer-centric, engage in price follower conduct and weaken the position of the dairies with their private label products. As a result of increasing import of milk and milk products Hungary became a net importer in recent years. Today, disposable income still essentially determines the consumption habits of price-sensitive consumers. Loyalty for Hungarian products is not typical, consumers are open for import products being preferred by retail chains. In addition Hungarian milk and milk product consumption is about half of the Union average and it is far behind the level being necessary for healthy eating. In Hungary lack of competitiveness and vertical integration relationships and backwardness are revealing among the dairy farmers and the dairies, while chain of stores are in unprecedented "monopolistic situation"; the whole sector can be characterised by defencelessness.
\end{abstract}

\section{INTRODUCTION}

The dairy sector can be divided into four basic stages: production of raw material, processing, trade and consumption. Precise demarcation of the each stage is difficult in many cases. Based on the determination of Salamon and Salamon (2004) "the stage of production ends with milking, processing still lasts until the delivery to the dealer. Stage of trade starts when the good arrives at the dealer and it lasts until the costumer pays at the checkout." General objective of present study is the problem analysis of the above-mentioned stages of dairy product chain - production, processing and trade (Figure 1.).

\section{Figure 1: Stages of dairy product chain}

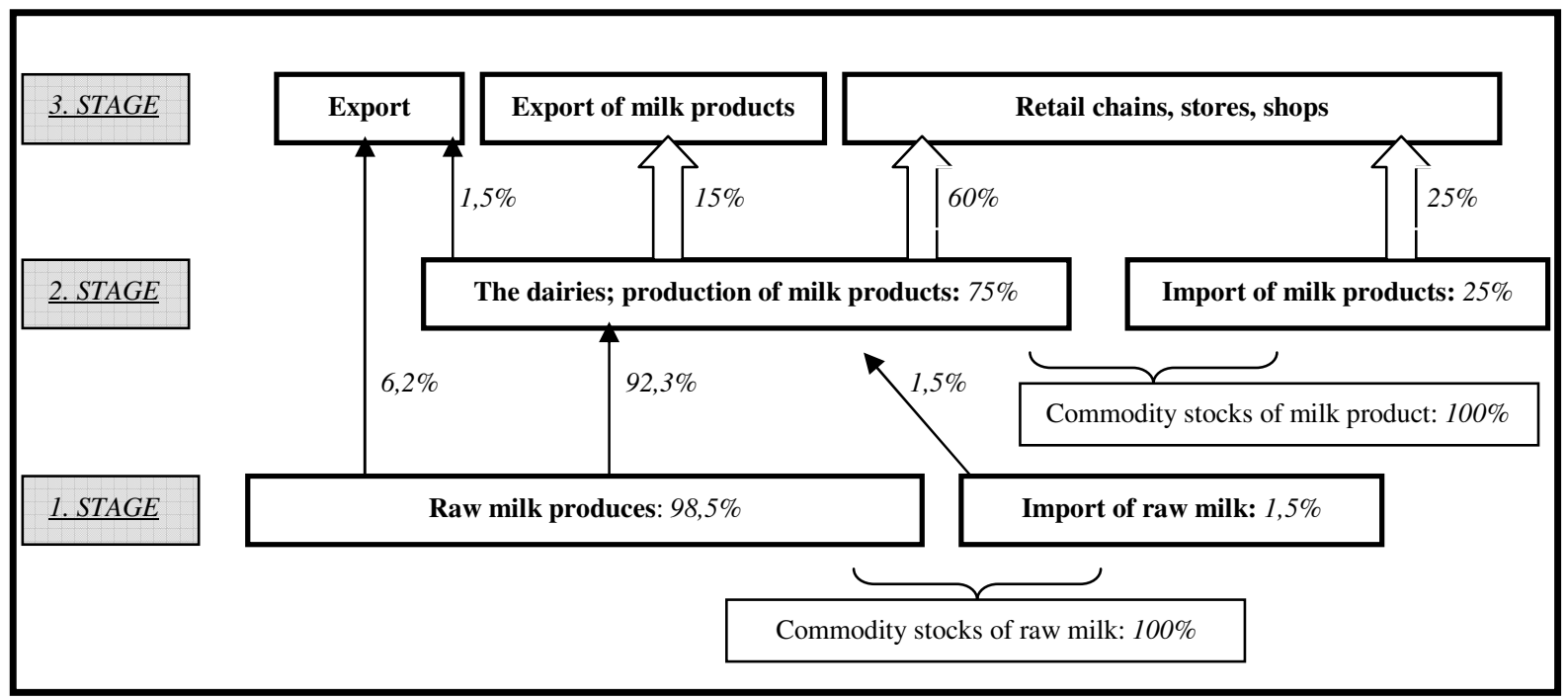

Source: Varga et. al., 2007 


\section{MATERIALS AND METHODS}

The present study carries out the problem analysis of the production, processing and commercial stages. I examine the production stage with the help of a problem tree, which is founded on secondary data collection and product chain information. Processing and commercial stages are presented together by means of a problem analysis. The next phase of this research is the creation of a problem tree of production by primary research, and the composition of a problem tree for the dairies and commercial sector on the basis of collected problems.

\section{THE SITUATION AND CHALLENGES OF MILK PRODUCTION IN HUNGARY}

As the problem tree of Figure 2. illustrates, Hungarian milk production can be characterized by low incomegenerating capacity. It essentially originates from two problems: on the one hand from the low purchase prices, on the other hand from the high net costs of dairy farmers. Several factors play important role in development of this two defining problems.

The size of Hungarian dairy herd decreased by $15 \%$ and milk production reduced by $14 \%$ in comparison with the data of the year preceding our accession to the European Union. On the basis of the KSH (2010) database the size of our dairy herd is currently 309 thousand heads, while the amount of milk production is 1712 million liter. Due to the low level of cooperation in production stage of dairy product chain negotiation power of dairy farmers is poor and they can be described by increased defenselessness against the rest of the product chain. In recent years only one significant producer organization was established in production stage of milk product chain, the Alföldi Tej Értékesítő és Beszerző Ltd., which managed to gain decisive market share. This producer organization was established in 2003, and it received the final recognition in 2005. The objective of this organization is the improvement of the profitability of milk production, on behalf of it the organization coordinates the following tasks: sale, production organization and consultancy, procurement, processing. The result of the increased defenselessness of dairy farmers is the weaker bargaining power against the dairies, which leads to low purchase prices. However purchase prices are depressed not only by the more concentrated processing sector, but the increasing presence of import products and the "unfavorable" product choice of pricesensitive consumers. Milk price became stable in 2007 and 2008 at a high level, internationally. Growing production and the economic crisis, however, led to a dramatic relapse in the price, leaving a number of producers in uncertainty (Borbély et. al., 2010). On the basis of AKI (2011) database price of raw milk was $66,32 \mathrm{HUF} / \mathrm{kg}$ in January 2010, however it was already 80,48 HUF/kg in December. In reference to the datum of January 2011 price of raw milk was $82,02 \mathrm{HUF} / \mathrm{kg}$, which was approximately higher by $24 \%$ compared to data of previous year.

Based on the experience of previous years it can be stated, that although the average milk yield of the Hungarian dairy herd - 6661 liter/cow/year based on KSH (2010) - is nearly 5\% above the EU average, nevertheless not the volume of yields is the most important in terms of the profitability of milk production, but the cost of production. Hungarian milk production is relatively expensive in comparison with the competitors (Popp et.al., 2008). Feeding costs represent the highest rate in cost structure of production, based on the statement of Vágó (2008) $43 \%$ of the costs is feeding cost. One reason for the high feeding costs is that dairy farms often do not have their own land to produce feed. If they can do they produce the necessary feed in leased land, however in worse case they base their production on purchased feed placing them even more vulnerable position. Moreover there is decreasing supply of the relatively cheap sugar-beet processing and cannery byproducts, which further complicates the situation of producers. Losses from animal health problems can not be disregarded in the cost structure of production. In Hungary annual loss caused by reproductive disorders is roughly 40-80 thousand HUF/cow, which can even be $9-11 \%$ of the farm's revenue. Another significant problem also causing serious losses is mastitis (Ózsvári, 2007). However further problem beside high feeding costs is our worse natural indicators, which are often caused by poor feed conversion and in many cases inefficient use of labour. All the above-mentioned factors contribute to the high net costs of dairy farmers. In 2008 centre of net costs was 75 HUF in case of defining commodity producers. The so-called better farms could produce milk $27 \%$ cheaper, for 55 HUF, while the less cot-effective farms produced milk for 84 HUF. The differences mainly arise from the costs of feeding (Béládi and Kertész, 2009).

Although the above-mentioned relative yield per cow is above the $\mathrm{EU}$ average, as regards the nutritive values Hungary falls behind the competitors. Compared with other Member States the average protein and fat content of domestic milk is relatively low, which in long run reduces the competitiveness of the dairies (Popp and Potori, 2010). Based on Mándi-Nagy (2011) the nutritive values of domestic raw milk are the followings: 3,29\% protein, $3,72 \%$ fat. Poor nutritional indicators may be primarily caused by high-yielding varieties, inappropriate housing and low nutriment content of forages.

On the one hand low income-generating capacity results in the lack of technological improvements, so production can be characterized by increasingly obsolete technology; while on the other hand several producers are ousted from the market choosing sales from house or entirely giving up production. All these factors could further deepen our already existing competitive disadvantage against the Western-European competitors. 
Figure 2: Problem tree of milk production stage

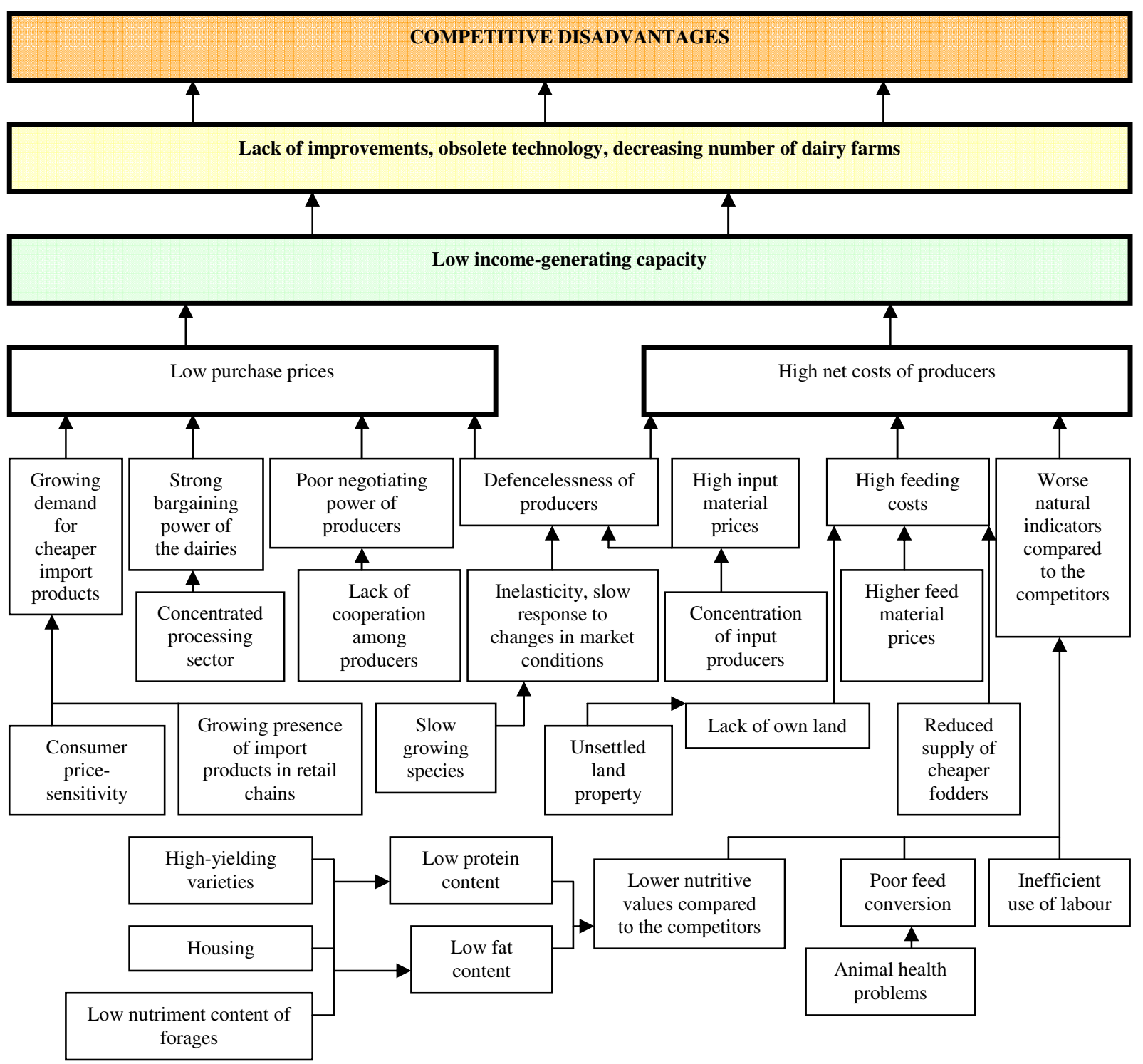

Source: Own work based on secondary data collection

\section{THE SITUATION AND CHALLENGES OF THE DAIRIES AND THE COMMERCIAL SECTOR}

Common and defining problem of the dairies and the commercial sector is the inadequate level of milk and milk product consumption. On the basis of KSH (2010) data base the per capita consumption of milk and milk products is about 160-180 liter/capita/year for ages in Hungary, and it was 172,9 liter/capita in 2008. This value is considerably lower than the EU average ( 260 liter/capita/year) and the healthy level of consumption (260270 liter/capita/year). Disposable income essentially determines the level of milk and milk product consumption of the Hungarian population. Hungarian consumers are not loyal for domestic products in many cases they choose the cheaper import products of retail chains. They are usually not aware of the features and components of products, do not know the origin of them and they are not interested in the method of production, i.e. they are not conscious and in the first place price influences their buying decisions. Lack of community marketing is typical in Hungary. However the successfulness of this sector exactly depends on the creation of consumer awareness and strengthening of health consciousness, to which community marketing tools should be invoked (Popp et. al., 2008). A survey carried out by Szakály et. al. (2005) also proved that in relation to milk and milk products significant misconceptions prevail among consumers. Essential interest of dairy industry is to clarify these existing misconceptions, since the lack of awareness building may have adverse effects on all categories of dairy products. Primary task is to strengthen consumer mentality among domestic products. Szakály et. al. (2005) and Major (2007) also emphasize the importance of community marketing, which is beneficial to the 
participants, because they can preserve the independence of their core activity, but apportion the costs of advertising, market research, exhibitions and product policy among each other. However sectoral and national community marketing activity can not function effectively without the establishment of producer organizations and marketing cooperatives. The most important finding of Szakály et. al. (2005) is that "the domestic community marketing can only be fully effective if a grassroots, marketing oriented system is managed to establish taking maximum into account the market needs and demands."

As described above the Hungarian consumer is specifically price-sensitive and less susceptible to the more expensive novelties. Nevertheless the domestic dairies are not able to compete with the cheaper, foreign mass products. Thus the market share of the domestic dairies continues to decline as a result of increasing import, which further reinforces the expansion of foreign dairy products (Popp et. al., 2010). Examining their values the import increased fivefold, while export doubled compared to the year prior our EU accession. Examining the product structure finished product sales are prevalent on the import side, while on the export side export of raw materials grew significantly. Our cheese export, which is primarily aimed at third countries, almost halved in the past. It must be highlighted that $80 \%$ of the import products come from the following four EU Member States: Germany, Poland, Slovakia, Czech Republic (Tej Terméktanács, 2010).

Another major problem of the dairies beside the low level of capacity utilization and the growing presence of import products is that their capacity utilization is estimated to reach only 50\%. As Popp et.al. (2010) also wrote the Western European dairies aspire to maximum capacity utilization and two- and three-shift operation, in contrast single-shift operation is typical in Hungary. Furthermore in case of international companies the role of work allocation increases, but in Hungary cooperation in the field of work allocation is still not considerable among the dairies, although the capacity utilization could be increased by it. In addition to the low level of capacity utilization the Hungarian dairies also lag behind the competitors in the sphere of innovation and product development. It basically has two reasons: first the medium-sized enterprises are deficient in funds and they have only few sources for research and development, on the other hand the well-capitalized companies are in significant proportion foreign-owned, so the innovative products are in many cases developed by the parent company and most often only the finished products are imported by the subsidiary (Popp, et.al., 2010).

During the examination of the production stage it was concluded that the bargaining and negotiating power of the producers are poor against the dairies representing more concentrated presence. However the dairies are already at a disadvantage against the commercial sector and like the producers have less bargaining power. Growing concentration in trade is a world trend which is caused by the emergence and sudden expansion of multinational retail chains. The aforementioned retail chains using their market weight are able to exert business pressure, i.e. buyer power on suppliers. The existence of buyer power means defenselessness for the suppliers, because the ever concentrated procurement of the large retail chains threatens the survival of the suppliers. The growing ratio of private label products in retail chains further increases the defenselessness of suppliers, since retail chains are also competitors for the suppliers adjusting the tool of price discrimination displacing the dairies' products. It is therefore concluded that the dairies concentrated slowly, while the commercial sector made it rapidly, thus currently the dairies are forced to surrender their income or a significant part of that to the trade, hereby their opportunities for development and innovation reduce and their competitiveness deteriorates (Popp and Juhász, 2011).

\section{PROPOSALS WITH RESPECT TO THE HUNGARIAN DAIRY SECTOR}

I collected future targets based on the proposals of the Hungarian Dairy Association, of which implementation could ensure economic hotspot for this industry. In my opinion the primary goal is to increase the size of our dairy herd to reach again the pre-accession level - 365 thousand heads - in the next 10 years. Parallel to the increase of the size of dairy herd milk production should also be increased and the quantity of produced milk should be determined in 2000 million kilograms per year again. Involving stakeholders it would be desirable to control the purchase price of milk with the definition of a minimum purchase price for a sixmonth period or with the application of a price-centre (Tej Terméktanács, 2010). In reference to the problem tree of the production stage each farmer should have as much land which is necessary for feed production and manure application (Popp et.al., 2008). One of the major objectives in this sector is to carry out competitiveness, but it requires the modernization of the dairies and the integration of the dairy farmers. The monopolistic situation of the retail sector should be forced back, along with it the appropriate ratio of domestic and import products should be $80-20 \%$. The increase of domestic milk and milk product consumption is an essential aspiration; the target is to achieve the $200 \mathrm{~kg} /$ capita/year consumption level (the consumption level of 1987). Use of community marketing tools is essential to increase the level of consumption and to influence consumer behavior (Tej Terméktanács, 2010). 


\section{REFERENCES}

AKI (2011): A nyerstej ára az EU-ban. https://www.aki.gov.hu/index.php

Béládi K.-Kertész R. (2009): A főbb mezőgazdasági ágazatok költség- és jövedelemhelyzete a tesztüzemek adatai alapján 2008-ban. Agrárgazdasági Információk, 2009/4. 51-64.

Borbély Cs.-Geszti Sz.- Szentgróti E.-Leonhardt B. (2010): A tejár változásának hatásai európai kitekintésben. Tejgazdaság, LXX. $2010 / 1-2$. 47-51.

KSH (2010): Statisztikai Tükör. Központi Statisztikai Hivatal, V. 3. 1-2.

Major V. É. (2007): Tej- és tejtermékek jelentősége az egészséges táplálkozásban - trendek. Élelmiszer, Táplálkozás és Marketing, IV. $1 / 2007.53-55$.

Mándi-Nagy D. (2011): Agrárpiaci jelentések - Tej és tejtermékek. Agrárpiaci jelentések, XIV. 2. 7.

Ózsvári L. (2007): 'Drága a tehén, ha sánta!' Magyar Mezőgazdaság, 62. 29. 38-39.

Popp J .-Juhász A. (2011): Az élelmiszerlánc szereplöi közötti kapcsolatok hazánkban. Gazdálkodás, 55. 1. 8-18

Popp J.-Potori N. (2010): Nemzetközi Agrárpiaci Kilátások. XIII. Magyarországi Mezőgazdasági Elörejelzési Konferencia, 60.

Popp J.-Potori N.-Papp G. (2010): A magyar tejvertikum diagnózisa. Gazdálkodás, 54. 1. 81-91.

Popp J.-Potori N.-Udovecz G. (2008): A versenyesélyek javításának lehetőségei az élelmiszergazdaságban. Agrárgazdasági tanulmányok, 2008. 107-114

Salamon L.-Salamon I. (2005): A versenyképesség javításának feltételei a tejvertikumban. AVA2, 2005. http://www.avacongress.net/ava2005/presentations/nkfp/7.pdf

Szakály Z.-Szente V.-Szigeti O. (2005): A hazai közösségi marketingben jelentkező anomáliák és feladatok. Élelmiszer, Táplálkozás és Marketing, II. 1-2/2005. 7-10.

Tej Terméktanács (2010): Agrárstratégia, A Tej Terméktanács javaslata a magyar tejvertikum vonatkozásában 2010-2020. http://www.tejtermek.hu/up/doc_news/agrarstrategia_7fb339bf.pdf

Varga T.-Tunyoginé N. V.-Kemény G. (2007): A fontosabb hazai termékpályák áralkuinak jellemzői. Gazdálkodás, 54.1 .18$.

Vágó Sz. (2008): Az árakra ható tényezők, az árak szerepe, árelőrejelzés a magyar tejvertikumban. Doktori (PhD) értekezés, Szent István Egyetem, Gödöllő. 83. 